\title{
Plasmid mediated virulence factors of some Proteus isolates
}

\author{
Khaled Z. El-Baghdady ${ }^{1}$, Mohammad M. Abooulwafa ${ }^{2}$, \\ Madeha O. Ghobashy ${ }^{1}$ and Hassan M. Gebreel ${ }^{1}$ \\ 1-Microbiology Department, Faculty of science, Ain Shams Univ., Cairo, Egypt. \\ 2-Microbiology \& Immunology Department, Faculty. of Pharmacy, Ain Shams Univ., \\ Cairo, Egypt.
}

\begin{abstract}
Various virulence factors including invasion, adhesion, cytotoxicity, protease, lipase, elastase, urease production and swarming migration were determined for 24 Proteus isolates recovered from clinical specimens. The results showed that the distribution of virulence factors was different among the test isolates and strain specific in most cases. All Proteus isolates showed invasion and adhesion capabilities with different extents. In addition, they were able to produce elastase, urease and exhibit swarming activity. Protease and lipase activities were not detected in any of the isolates. High cytotoxicity was demonstrated in all isolates. A parallel correlation between invasion and cytotoxicity was demonstrated in all isolates. Five isolates of high virulence factors productivities were selected and identified by Analytical Profile Index as Proteus mirabilis (Pr2, Pr12 and Pr24) and Proteus penneri (Pr6 and Pr20). Plasmid curing by acridine orange resulted in the loss of invasiveness and adhesion capabilities of the five isolates, while other virulence factors levels showed no significant difference changes. The results give a clear evidence that both invasion and adhesion of the tested Proteus isolates are plasmid rather than chromosomally encoded.
\end{abstract}

Key words: Proteus, virulence, invasion, adhesion, urease, plasmid and curing

INTRODUCTION

Proteus species, members of the family Enterobacteriaceae (Penner, 1984) are motile Gram negative enteric bacteria, they are important pathogens of the urinary tract and are the primary infectious agent in patients with indwelling urinary catheters (Warren et al., 1982). Individuals suffering from urinary tract infections caused by Proteus mirabilis often develop bacteriuria, cystitis, kidney and bladder stones, catheter obstruction due to stone encrustation, acute pyelonephritis, and fever (Mobley and Warren, 1987; Johnson et al., 1993 and Burall et al., 2004). In addition strains of Proteus penneri can also cause urinary tract infection (Krajden et al., 1984).

Several potential virulence factors of Proteus had been studied in relation to its virulence and pathogenicity of urinary tract, including hydrolysis of urea by urease, cell invasiveness, cytotoxicity induced by hemolysins, cleavage of IgA and IgG by proteolytic enzyme and adherence to the uroepithelium mediated by fimbriae (Coker et al., 2000).

There were many proposed mechanisms and influencing factors for the invasive properties of $P$. mirabilis (Korn et al., 1995). Microbial invasion could be facilitated by virulence factors, microbial adherence, and resistance to antimicrobials. Virulence factors assisted pathogens in invasion and resistance of host defences. Bacterial proteins with enzymatic activity (e.g. protease, hyaluronidase, neuraminidase, elastase, collagenase) facilitated local 
tissue spread. Microbial adherence to surfaces helps microorganisms establish a base to penetrate tissues. The adhesive properties in the Enterobacteriaceae were generally mediated by different types of pili (Ofek and Doyle, 1994).

Urease, which is responsible for the formation of bladder and kidney stones at later stages of infection, could facilitate the colonization of the urinary tract in a mouse model (Jones et al., 1990). Haemolysin, which is cytotoxic for cultured urinary tract epithelial cells (Mobley et al., 1991), had been shown to be correlated with the ability of bacteria to invade cells (Peerbooms et al., 1984). The ability of $P$. mirabilis to express virulence factors, including urease and haemolysin, and to invade human urothelial cells, is coordinately regulated with swarming differentiation (Allison et al., 1992; Liaw et al., 2000, 2001 and 2004).

Swarming cell differentiation is thought to be important for the virulence of $P$. mirabilis during urinary tract infections (UTIs) since several virulence factors, including flagellin, urease, the hemolysin HmpA, and the IgA metalloprotease ZapA, are upregulated in the differentiated swarmer cell compared to swimmer cells (Allison et al., 1992 and Fraser et al., 2002).

A tight relationship between bacterial cells harbouring plasmids and their drug resistance profile was known (Maltezou, 2009). Extendedspectrum $\beta$-lactamases (ESBLs) are enzymes that compromise the efficacy of all $\beta$-lactams by hydrolysis of the $\beta$-lactam ring (Coque et al., 2008). The genes encoding ESBLs were usually located on plasmids that were highly mobile and can harbour resistance genes to several other unrelated classes of antimicrobials (Canton and Coque, 2006).

Virulence factors of pathogenic bacteria (adhesins, toxins, invasins, protein secretion systems, iron uptake systems, and others) may be encoded on chromosomal DNA, bacteriophage DNA, plasmids, or transposons (Johnson et al., 2003) in particular regions of the prokaryotic genome termed pathogenicity islands (PAIs). Pathogenicity islands were first described in human pathogens of the species Escherichia coli, but have recently been found in the genomes of various pathogens of humans, animals, and plants (Haker and Kaper, 2000 \& Perna, et al., 2001)

Understanding of the common themes in microbial pathogenicity is essential to recognize the microbial virulence in order to develop novel vaccines and other therapeutic agents for the treatment and prevention of infectious diseases. Accordingly, the aim of this work was to quantify some potential virulence factors produced by some Proteus spp. and study whether they were chromosomal or plasmid coded.

\section{MATERIALS AND METHODS} Specimens and bacterial isolation

Fifty clinical specimens were collected from El-Demerdash hospital and Ain Shams Special hospital. The collected specimens included urine and swabs from wounds and abscesses. In addition, one isolate was supplied from hospital microbiological labs as grown culture which was recovered from prostatic secretions. Clinical specimens were collected according to the methods described by Cheesbrough (2000).

\section{Maintenance of clinical isolates}

All bacterial clinical isolates were grown routinely on nutrient agar slants, stored at $4^{\circ} \mathrm{C}$ and subcultured monthly. For long term storage, 
bacterial isolates were grown in nutrient broth medium at $37^{\circ} \mathrm{C}$ to exponential phase and spinned down at $10,000 \mathrm{xg}$ for $10 \mathrm{~min}$. The pellet was resuspended in $10 \%(\mathrm{v} / \mathrm{v})$ sterile glycerol in Protect Vials (Technical Service Consultants Ltd., UK) and stored at $-20^{\circ} \mathrm{C}$.

\section{Vero Cell Line}

Vero cell line used in this study was purchased from tissue culture department of VACSERA, Egypt. Vero cell line (ATCC No.CCL-81) is a Kidney epithelial cells derived from African green monkey (Ceropithecus aethiops). Preparation of Vero cell monolayer in microtiter plates was carried out according James and John (1998).

\section{Identification of clinical isolates}

Identification of clinical isolates

for preliminary screening was carried out according to Bergey's Manual of Systematic Bacteriology (Holt and Williams, 1989). The identification of selected isolates was confirmed by Analytical Profile Index (API NE and API 20E (for Enterobacteriaceae) from Biomerex France).

Quantitative assay of virulence factors Preparation of bacterial inoculum

A twenty four hours tryptic soy broth cultures of tested microorganisms grown in shaking incubator were centrifuged, washed twice with PBS and then standardized to $10^{8} \mathrm{CFU} \mathrm{ml}{ }^{-1}$ using nutrient broth medium (for protease, elastase, lipase and urease assays) while in case of assay of invasion, adherence and cytotoxcity, Basal tissue culture medium (BTC) was used to standardized the inoculum to $10^{8}$ CFU ml ${ }^{-1}$.

Growth conditions for production of virulence factors by the tested isolates

A set of $250 \mathrm{ml}$ flasks containing $50 \mathrm{ml}$ tryptic soya broth was separately inoculated by the tested isolated $\left(100 \mu 1\right.$ of $\left.10^{8} \mathrm{CFU} \mathrm{ml}{ }^{-1}\right)$. The flasks were incubated in shaking incubator for $24 \mathrm{~h}$ at $37^{\circ} \mathrm{C}$. The growth obtained was centrifuges at $10000 \mathrm{rpm}$ for $10 \mathrm{~min}$. and the culture supernatants obtained were used for assaying extracellular virulence factors (protease, lipase and elastase). While for urease assay the pellets were used after sonication.

Quantitative assay of adherence and invasion

Adherence and invasion assay was carried out as described by Plotkowaski et al. (1994). Monolayers were grown in 96-well plates and inoculated. After incubation, monolayers were infected by addition of $100 \mu$ of each clinical isolate suspended in Basal tissue culture medium (BTC). After incubation for $2 \mathrm{~h}$ at $37^{\circ} \mathrm{C}$ in $\mathrm{CO}_{2}$ incubator, medium were discarded and the wells were rinsed three times with phosphate buffer saline (PBS).

To assess adherence, monolayers were lysed with lyses solution for $10 \mathrm{~min}$ at room temperature. Following lyses, bacteria were enumerated by plating ten fold serial dilution onto nutrient agar medium to calculate the total count of adhered and up taken bacterial cells.

\section{Quantitative assay of invasion}

Invasion was determined as described by Plotkowaski et al. (1994), using a gentamycin survival assay. The same procedure was constructed as previously mentioned. After incubation at $37^{\circ} \mathrm{C}$ for $2 \mathrm{~h}$, infected monolayers were rinsed three times with PBS. Monolayers were then incubated for $2 \mathrm{~h}$ with fresh tissue culture medium containing 100 $\mu \mathrm{l}$ gentamicin $\left(500 \mu \mathrm{g} \mathrm{ml}^{-1}\right)$ for each well to kill extracellular bacteria and incubated for $1 \mathrm{~h}$. Following incubation, monolayers were rinsed, lysed, and bacteria were enumerated as for the adherence assay. By subtracting the number of invading cells from the total count of adhered and uptaken 
cells, the number of adhering cells was obtained. Eight replicates wells were used for each isolate and all tests were performed at least twice.

\section{Quantitative assay of cytotoxicity}

This assay was carried out according to Kueng et al. (1986). Crystal violet assay were used to measure the total count of mammalian cells which well reflect the cytotoxic effects of the different selected clinical isolates by using Vero cell line in 96 well plates. The cell culture type (Vero) was subcultured in microtiter plate and each well was inoculated with $20 \mu \mathrm{l}$ of each clinical isolates (suspended in BTC medium). The plates were incubated for $24 \mathrm{~h}$ in $\mathrm{CO}_{2}$ incubator at $37^{\circ} \mathrm{C}$. After incubation time, the medium was discarded and the wells were washing three times with sterile saline solution, $100 \mu \mathrm{l}$ of gluteraldehyde of $1 \%$ was added for about 30 minutes. The excess gluteraldehyed solution was removed then washed with tap water. Crystal violet solution $(0.1 \%), 100 \mu \mathrm{l}$ was added for about 30 minutes, dispensed and washed with very slow rate of tap water. The plates were dried then the stained wells were eluted with $100 \mu \mathrm{l}$ of $10 \%$ acetic acid solution. The color intensity in each well was measured using microplate reader at $290 \mathrm{~nm}$. Eight replicates were used for each isolate, and all tests were performed at least twice.

The absorption reading of clinical isolates (average reading of 8 wells) divided by the control reading (average reading of 8 wells containing $20 \mu \mathrm{l}$ of sterile BTC medium instead of bacterial suspension) multiplied by $10^{4}$ (the total number. of Vero cell per well). This provides the number of viable Vero cells. Subsequently, the previous number was subtracted from
$10^{4}$ to obtain the number of dead Vero cells.

\section{Quantitative assay of protease activity}

Azo-albumin test was performed as described by Ayora et al. (1994) with slight modification, $0.3 \mathrm{ml}$ of bacterial culture supernatant was added to a test tube, $1.7 \mathrm{ml}$ of distilled water, and then $0.1 \mathrm{ml}$ of azo albumin suspension $\left(5.0 \mathrm{mg} \mathrm{ml}^{-1}\right.$ in $0.1 \mathrm{M}$ Tris buffer $\mathrm{pH}$ 7.5). Blank containing $2.0 \mathrm{ml}$ of distilled water and $0.1 \mathrm{ml}$ of azo albumin suspension. Test tubes were incubated for one hour in a water bath at $30^{\circ} \mathrm{C}$ then 2.0 $\mathrm{ml}$ of $8 \%$ TCA were added to stop the reaction. The mixture then poured into a polypropylene centrifuge tube and centrifuged at $10,000 \mathrm{xg}$ which was sufficient to precipitate the protein. To a clean tube $2.0 \mathrm{ml}$ of clear supernatant was transferred and mixed with $2.0 \mathrm{ml}$ of $0.5 \mathrm{M} \mathrm{NaOH}$ to intensify the color. The absorption was measured at $400 \mathrm{~nm}$. The optical density was used for determination of the amount of protease enzyme $\mathrm{U} \mathrm{ml}^{-}$ ${ }^{1}$ using a standard curve of protease.

\section{Quantitative assay of lipase activity}

Determination of liberated free fatty acid (FFA), as a result of lipase activity was measured by the modified method of Kwon and Rhee (1986). Olive oil was used as a substrate. The reaction mixture 1.0 $\mathrm{ml}$ of bacterial free supernatant, 2.5 $\mathrm{ml}$ emulsion of $(50 \mathrm{ml}$ olive oil in $50 \mathrm{ml} \mathrm{PBS}$ ) and $0.02 \mathrm{ml}$ of $20 \mathrm{mM}$ $\mathrm{CaCl}_{2} \cdot 2 \mathrm{H}_{2} \mathrm{O}$ was incubated in shaking incubator at $200 \mathrm{rpm}$ for 30 $\min$, at $37^{\circ} \mathrm{C}$. Then the reaction was stopped by adding $1.0 \mathrm{ml} 6 \mathrm{~N} \mathrm{HCl}$ and then $5.0 \mathrm{ml}$ of iso-octane. The upper layer $(4 \mathrm{ml})$ was pipette out into a test tube and $1.0 \mathrm{ml}$ of cupric acetate pyridine was added. The free fatty acid dissolved in iso-octane was determined by measuring the absorbance of iso-octane solution at 
$715 \mathrm{~nm}$. Lipase activity was determined by measuring the amount of FFA from the standard curve of oleic acid.

Quantitative assay of elastase activity

Elastase activity in bacterial suspension was measured as described by Furuya et al. (1993). Bacterial suspension supernatant 0.1 $\mathrm{ml}$ was diluted three-fold with 10 $\mathrm{mM}$ Tris ( $\mathrm{pH} 7.5)$ and added to $2 \mathrm{ml}$ of $2 \mathrm{mg}$ of elastin congo red (Sigma Chemical Co., St. Louis, Mo.) suspended in $20 \mathrm{ml}$ of PBS as a substrate. The mixture $(2.4 \mathrm{ml})$ was incubated at $37^{\circ} \mathrm{C}$ for $1 \mathrm{~h}$, with vigorous shaking. The undissolved substrate was removed by centrifugation at $3000 \mathrm{xg}$ for $10 \mathrm{~min}$. absorbance was measured at OD 495. Values of the supernatants were then compared with a standard curve prepared by treating the substrate with purified $P$. aeruginosa elastase (Elastin Products Co., Inc., Owensville, MS, USA) for the same period at enzyme concentrations of 0.75-100 $\mathrm{gg}^{-1}$.

\section{Quantitative assay of urease activity}

Urease activity of bacterial cell extracts was determined by measuring the amount of ammonia released from urea in the phenolhypochlorite urease assay (Weatherburn, 1967). Bacterial pellets (produced by centrifugation of $2 \mathrm{ml}$ of bacterial suspension) were sonicated in $1 \mathrm{ml}$ of urease buffer (50 mM HEPES pH 7.5 plus $25 \mathrm{mM}$ urea) then incubated at $37^{\circ} \mathrm{C}$ for $20 \mathrm{~min}$. The reaction was stopped by removal of $1 \mathrm{ml}$ aliquots to cuvettes containing $1.5 \mathrm{ml}$ of solution A (10 $\mathrm{g} \mathrm{l}^{-1}$ of phenol and 50 mg of sodium nitroprusside) and 1.5 $\mathrm{ml}$ of solution $\mathrm{B}\left(\mathrm{NaOH} 5 \mathrm{mg} \mathrm{ml}^{-1}\right.$ $\mathrm{NaClO} 0.044 \%$, v/v). The contents were mixed thoroughly. Following incubation at $37^{\circ} \mathrm{C}$ for $30 \mathrm{~min}$, the absorbance was measured at $625 \mathrm{~nm}$. A standard curve was prepared using ammonium chloride concentrations (0.1-1 $\left.\mu \mathrm{g} \mathrm{ml}^{-1}\right)$.

Assay of swarming migration behavior

The swarming migration distance assay was performed as described by (Gygi et al., 1995 and Liaw et al., 2001). Briefly, an overnight bacterial culture $(5 \mu \mathrm{l})$ was inoculated centrally onto the surface of dry LB agar medium (with $2 \%$ agar, w/v) plates. After incubation at $37^{\circ} \mathrm{C}$, swarming migration for the bacterial cells was detected every 30 min. till $18 \mathrm{~h}$.

\section{Plasmid DNA extraction}

Plasmid DNA was extracted and purified from a $5 \mathrm{ml}$ overnight cultures of the selected isolates grown in LB broth medium using a QIA prep Spin Miniprep kit (Qiagen) according to the manufacturer's instructions.

\section{Agarose gel electrophoresis}

Agarose gel electrophoresis was used to separate DNA fragments according to size. Agarose (GibcoBRL) was mixed with $1 \mathrm{x}$ TAE to a final concentration of $1 \%$ $(\mathrm{w} / \mathrm{v})$ and boiled to dissolve. Ethidium bromide was added to the gel at a final concentration of $0.25 \mu \mathrm{g}$ $\mathrm{ml}^{-1}$ before casting in standard horizontal gel equipment, $1 \mathrm{~kb}$ DNA ladder (Fermentas) was used as molecular markers to size DNA fragment. DNA samples $(15 \mu \mathrm{l})$ were mixed with one fifth volume of loading buffer. Electrophoresis was carried out at $80-100 \mathrm{~V}$ for $1-2 \mathrm{~h}$ in TAE buffer. After electrophoresis, gels were visualized using a short wave UV trasilluminator (Spectroline, USA) and fluorescent images were captured.

\section{Plasmid curing}

\section{Plasmid curing by SDS}

The curing was carried out according to Tolmasky et al., (1993). One $\mathrm{ml}$ of CA-YE broth medium containing 10\% SDS was inoculated with $10 \mu \mathrm{l}$ of an overnight culture 
then incubated at $37^{\circ} \mathrm{C}$ for $24 \mathrm{~h}$. Two fold dilutions were made, after that, $10 \mu \mathrm{l}$ was streaked over CA-YE-2 agar medium plates and incubated at $37^{\circ} \mathrm{C}$ for $24 \mathrm{~h}$. The separate colonies (mutants) were resubcultured on CAYE-2 plates to ensure their purity. These isolates were tested for their antibiotic sensitivity and presence of plasmids.

\section{Plasmid curing by acridine orange}

LB broth tubes containing (different concentrations of acridine orange to a final concentration of 10 , $15,20,25,30,32.5$ and $35 \mu \mathrm{g} \mathrm{ml}^{-1}$ ) were inoculated with an overnight culture of clinical isolates. The tubes were incubated at $37^{\circ} \mathrm{C}$ for $24 \mathrm{~h}$. The highest concentration of acridine orange that showed turbidity $(0.7-0.8$ at OD $660 \mathrm{~nm}$ and the isolate still viable) was selected. The selected tubes were plated on LB agar medium and incubated at $37^{\circ} \mathrm{C}$ for 24 h. The cured isolates were tested for their antibiotic sensitivity and presence of plasmids.

\section{Antibiotic sensitivity test}

Antibiotic sensitivity test was carried to study the multi-drug resistant patterns of Proteus isolates bacteria. Different antibiotics namely Ciprofor, Garamycin, Cefotax, Isoptophenicol, Terramycin, Amikin, Cefteriaxone, Sulperazone, Cefobid, Leeflox, Meronam, Fortum, Tetracid, Tienam, Tazocin, Augmenten, Unacyine and Amoxile were tested. Nutrient agar plates were surface inoculated with $20 \mu \mathrm{l}$ of $24 \mathrm{~h}$ bacterial inoculum prepared as mentioned in section 2.2 and then discs of different antibiotics were placed uniformly on the surface of the plate. Plates were incubated at $37^{\circ} \mathrm{C}$ for $24 \mathrm{~h}$. The sensitivity and resistance of the isolates were determined according to the Performance Standards for Antimicrobial Disk Susceptibility Tests
(Gram negative antibiotic susceptibility guide GlaxoWellcome).

\section{Statistical analysis}

All statistical analysis in this study was carried out using Microsoft Excel 2000, Analysis Toolpack (Microsoft Corporation). All data were calculated from at least 3 replicates and the standard error for each datum was plotted on the graph.

\section{RESULTS}

Preliminary identification of clinical isolates

Twenty four isolates of Proteus spp. were recovered from different clinical isolates and preliminary identified by different biochemical tests according to the methods recommended by (Holt and Williams, 1989 \& cheesbrough, 2000) Table 1.

Table (1): Biochemical tests for identification of Proteus spp. the clinical isolates.

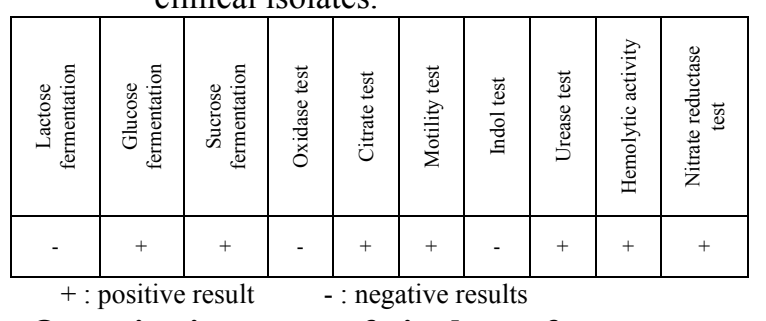

Quantitative assay of virulence factors Proteus isolates were predominant in urine samples about 18 isolates $(75 \%)$, followed by 5 isolates from wound swab (21\%), and only 1 isolate from prostatic secretion (4\%), hence, Proteus spp. considered as a major pathogen of urinary tract infection (Table 2).

All Proteus isolates demonstrated high invasion capability on vero cells with a maximum invasiveness recorded with Pr12 and Pr2 $38 \times 10^{4}$ and $41 \times 10^{4} \mathrm{CFU} \mathrm{ml}{ }^{-1}$ respectively. Adherence capability of Proteus spp. showed that $\operatorname{Pr} 12$ had maximum adherence $\left(45 \mathrm{x} \quad 10^{4}\right.$ CFU $\left.\mathrm{ml}^{-1}\right)$ compared with other isolates. A variable cytotoxicity of Proteus spp. towards vero cells ranged from 3774 
to 6702 dead cells was recorded (Table 2).

Table (2): Virulence factors of Proteus spp. isolated from different clinical samples. The highlighted rows represent the selected spp. for further investigations.

\begin{tabular}{|c|c|c|c|c|c|c|c|}
\hline 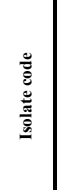 & 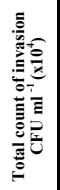 & 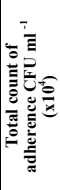 & 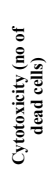 & 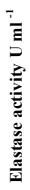 & 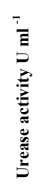 & 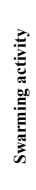 & 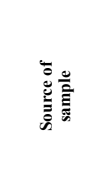 \\
\hline Pr 1 & 20 & 7 & 5542 & 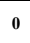 & 99 & + & Urine \\
\hline $\operatorname{Pr} 2$ & 41 & 36 & 5560 & & 133 & + & Urine \\
\hline $\operatorname{Pr} 3$ & 22 & 7 & 5232 & & 59 & + & Prostatic pu \\
\hline $\operatorname{Pr} 4$ & 25 & 5 & 5232 & 4 & 89 & + & Urine \\
\hline $\operatorname{Pr} 5$ & 26 & 4 & 5534 & 0 & 79 & + & Urine \\
\hline $\operatorname{Pr} 6$ & 30 & 29 & 6074 & 6 & 146 & + & Urine \\
\hline Pr 7 & 18 & 3 & 5068 & 0 & 92 & + & Urine \\
\hline Pr 8 & 20 & 8 & 5480 & 4 & 88 & + & Urine \\
\hline Pr 9 & 27 & 4 & 5263 & 0 & 86 & + & Urine \\
\hline Pr 10 & 29 & 6 & 4396 & 0 & 79 & + & Wound pus \\
\hline Pr 11 & 19 & 17 & 4935 & 0 & 73 & + & Urine \\
\hline Pr 12 & 38 & 45 & 6702 & 7 & 145 & + & Urine \\
\hline Pr 13 & 19 & 5 & 5535 & 4 & 70 & + & Urine \\
\hline Pr 14 & 17 & 2 & 4245 & 5 & 102 & + & Urine \\
\hline $\operatorname{Pr} 15$ & 20 & 3 & 4130 & 0 & 88 & + & Abscess swab \\
\hline Pr 16 & 28 & 5 & 5263 & 0 & 91 & + & Urine \\
\hline Pr 17 & 20 & 4 & 4706 & 0 & 84 & + & Urine \\
\hline Pr 18 & 23 & 5 & 5220 & 0 & 90 & + & Wound swab \\
\hline Pr 19 & 27 & 3 & 3774 & 2 & 87 & + & Urine \\
\hline $\operatorname{Pr} 20$ & 28 & 19 & 6471 & 7 & 154 & + & urine \\
\hline Pr 21 & 24 & 4 & 4706 & 0 & 85 & + & Wound pus \\
\hline Pr 22 & 23 & 3 & 5135 & 0 & 97 & + & Urine \\
\hline Pr 23 & 16 & 5 & 5466 & 0 & 80 & + & Wound swab \\
\hline $\operatorname{Pr} 24$ & 32 & 6 & 6625 & 5 & 129 & + & Urine \\
\hline
\end{tabular}

For enzymatic activities, Proteus isolates did not show any protease or lipase activities. However, only 10 isolates were able to produce very low concentration of elastase enzyme ranged between 2 and $7 \mathrm{U} \mathrm{ml}^{-1}$ (Table 2). For urease activity, all Proteus isolates showed urease production with activity ranged from 59 to $154 \mathrm{U} \mathrm{ml}^{-1}$. Maximum urease activity was recorded with Pr20 (Table 2). All Proteus isolates showed swarming ability on swarming agar medium.

Depending on the previous results, 5 Proteus spp. $\operatorname{Pr} 2, \operatorname{Pr} 6, \operatorname{Pr} 12$, $\operatorname{Pr} 20$, and Pr24 showed maximum production of several virulence factors (Table 2), were selected for further investigations.

\section{Identification of selected clinical isolates}

The selected isolates were identified by Analytical Profile Index (API). Pr2, Pr12 and Pr24 were identified as Proteus mirabilis while Pr6 and Pr20 were identified as Proteus penneri (Table 3 ).

Table (3): Identification of the selected clinical isolates by Analytical Profile Index (API).

\begin{tabular}{|c|c|}
\hline Clinical isolates & Identification \\
\hline $\operatorname{Pr} 2$ & Proteus mirabilis \\
\hline $\operatorname{Pr} 6$ & Proteus penneri \\
\hline $\operatorname{Pr} 12$ & Proteus mirabilis \\
\hline $\operatorname{Pr} 20$ & Proteus penneri \\
\hline $\operatorname{Pr} 24$ & Proteus mirabilis \\
\hline
\end{tabular}

\section{Antibiotic sensitivity test}

Sensitivity of the identified clinical isolates towards 18 standard antibiotics (representing 8 classes) was carried out to confirm the multi-drug resistance of these isolates (Table 4).

Table (4): Diameter of inhibition zones of different antibiotics $(\mathrm{cm})$ against the selected clinical isolates.

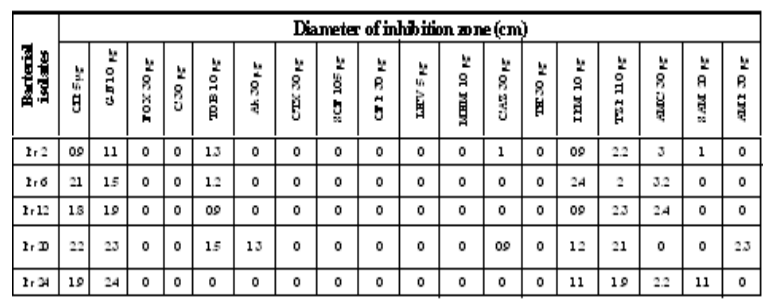

CIP: Ciprofor, GN: Garamycin, FOX: Cifteriaxone, C: Isoptophenicol, TOB: Terramycin, Ak: Amikin, CTX: Cefotax, SCF: Sulperazon, CFP: Cefobid, LEV: Leeflox, MEM: Meronam, CAZ: Fortam, TE: Tetracid, IPM: Tienam, TZP: Tazocin, AMC: Augmentin, SAM: Unasyin and AMP: Amoxile.

The sensitivity and resistance of the isolates were determined according to the Performance Standards for 
Antimicrobial Disk Susceptibility Tests (Gram negative antibiotic susceptibility guide GlaxoWellcome). Cifteriaxone, Cefotax and Sulperazon antibiotics did not show any inhibitory activity against any of the tested isolates. Proteus spp. showed susceptibility towards different antibiotics. Tazocin showed activity against the 5 Proteus clinical isolates. Pr20 was the most sensitive among the others (Table 4).

Plasmid pattern of selected clinical isolates

To assess the relation between plasmids and virulence factors, plasmid extraction from the selected isolates was carried out and analyzed by electrophoresis on $1 \%$ agarose gel. All isolates were harbouring plasmids, however, the same pattern was observed with plasmid isolated from Pr2, Pr6 and Pr12 (Fig. 1).

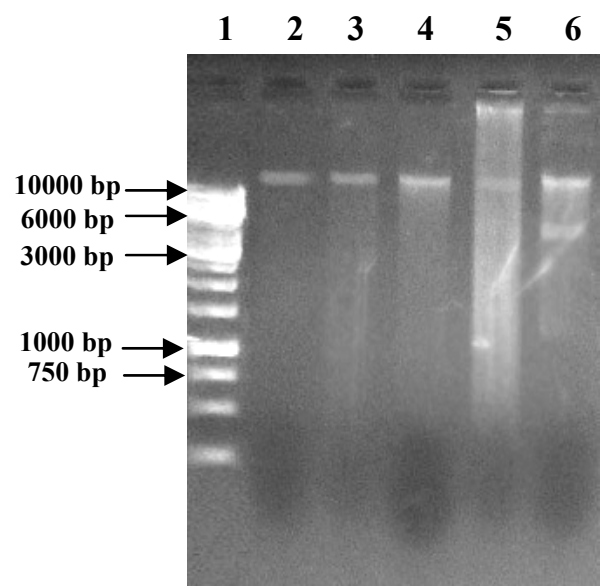

Fig. 1: Electrophoresis of plasmid DNA isolated from the Proteus spp. Lane 1 is $1 \mathrm{~kb}$ DNA ladder1-; lanes, 2, 3, 4, 5 and 6 are plasmids isolated from $\operatorname{Pr} 2, \operatorname{Pr} 6, \operatorname{Pr} 12$, Pr20 and Pr24 respectively

\section{Plasmid curing}

To demonstrate whether the virulence factors of the selected clinical isolates were plasmid or chromosomal origin, plasmid curing was carried out. Two methods were employed for plasmid curing, the first one by treatment with $10 \%$ SDS.
This method showed partial curing i.e. did not remove plasmids completely.

The second method was treatment with different concentrations of acridine orange. The best concentration of acridine orange used to cure plasmids was $32.5 \mu \mathrm{g} \mathrm{ml}^{-1}$ at which the OD at $660 \mathrm{~nm}$ ranged from 0.7 to 0.8 . Complete plasmid curing was confirmed by plasmid extraction and sensitivity of the cured isolates towards different antibiotics which were resistant to them before.

Effect of plasmid curing on virulence factors

Virulence factors were measured in the selected isolates before and after curing the cells from plasmid to assess the relation between virulence factors and presence of plasmids.

All isolates were found to loose their invasive capability upon plasmid curing (Fig. 2). In addition, the ability to adhere and colonize to the vero cells was lost after plasmid curing. Plasmid free isolates showed no significant difference in cytotoxicity compared with the wild type isolates (non-cured) (Fig. 2). The same pattern was obtained with the other virulence factors elastase and urease activities which showed no significant difference before and after plasmid curing (Fig. 2). Moreover, measuring swarming after growing the wild types and the mutants for $7 \mathrm{~h}$ showed no significant difference in swarming migration diameter (Fig. 2). 
W. t. (before curing)

Mutant (after curing)

A

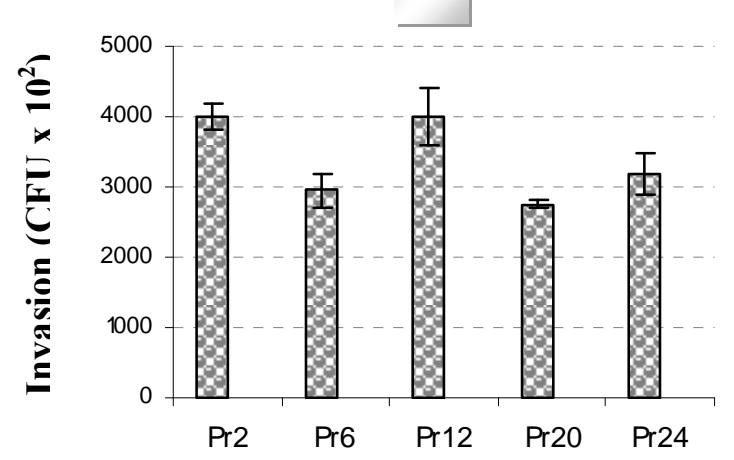

C

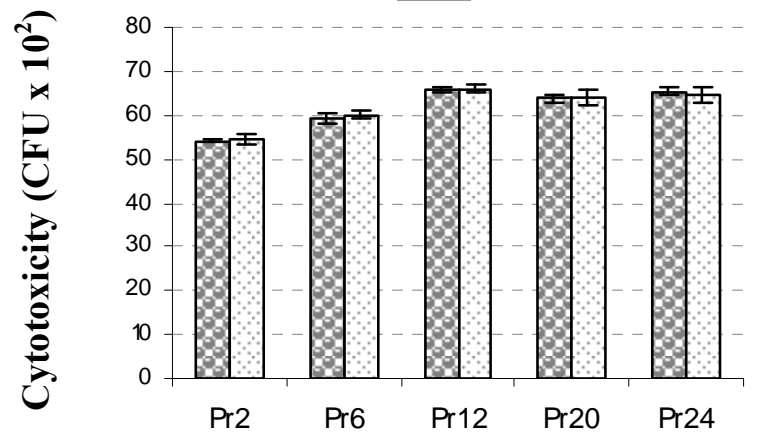

$\mathbf{E}$

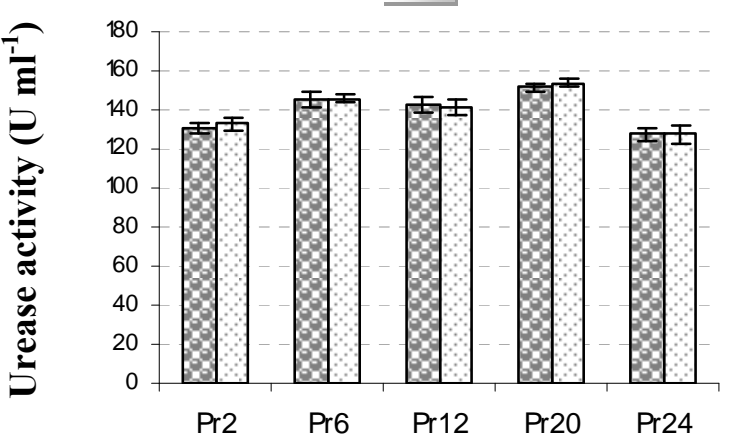

B

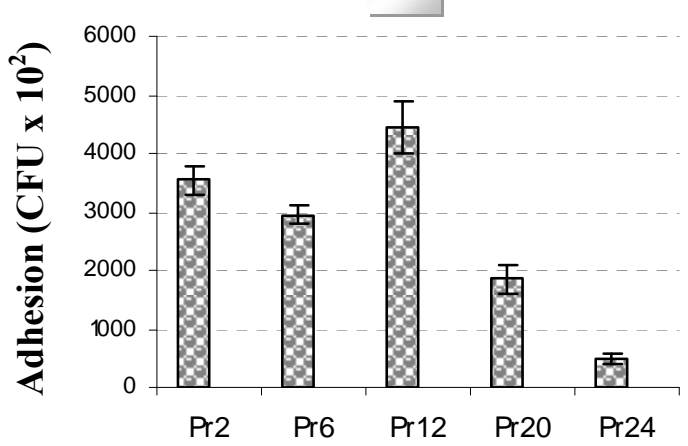

D

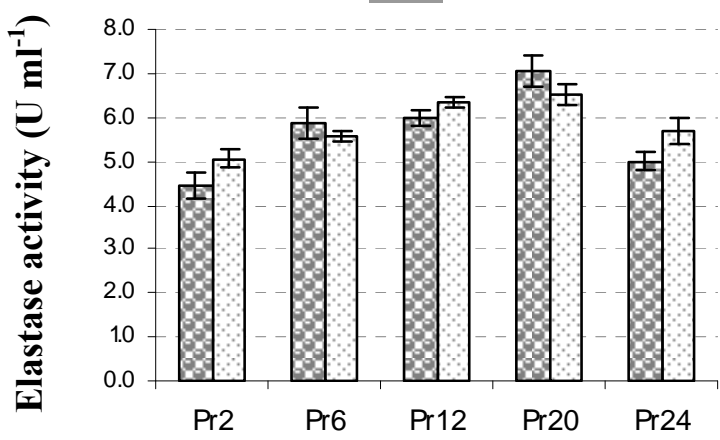

F

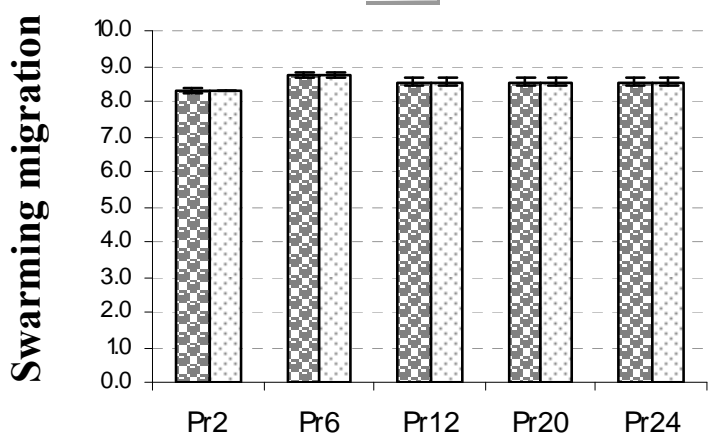

Fig. 2: Effect of plasmid curing on different virulence factors of the selected Proteus clinical isolates. A, invasion; $\mathrm{B}$, adhesion; C, cytotoxicity; D, elastase activity; E, urease activity and F, swarming migration after $7 \mathrm{~h}$. W. t., wild type. 


\section{DISCUSSION}

Recently, significant evidence indicated that markedly different microbial pathogens use common strategies to cause infection and disease (Tang et al., 1995). Many diverse bacterial pathogens share common mechanisms in terms of their abilities to adhere, invade, and cause damage to host cells and tissues, (Finlay and Falkow, 1997) as well as to survive host defenses and establish infection. Many of these infections appeared to be related to the acquisition of large blocks of virulence genes from a common microbial ancestor, which can be disseminated to other bacteria via horizontal transfer (Hentzer and Givskov, 2003).

In the present study, a total of 24 clinical bacterial isolates were isolated from different collected clinical specimen from patient suffering from urinary tract infection, wound, burn and abscesses infections. The ability of all clinical isolates to produce different virulence factors including invasion, adherence, cytotoxicity, production of protease, lipase, elastase, urease as well as swarming migration were investigated.

All tested isolates showed variable production of different virulence factors, however all of them sharing certain virulence factors.

The isolates could be classified as either invasive according to gentamycin survival assay or cytotoxic according to crystal violet dye exclusion assays. The results showed that all Proteus spp. isolates exhibited both high invasion capability and epithelial cell cytotoxicity. This was reported by Jacobsen et al. (2008) who reviewed invasion, cytotoxicity and biofilm formation of Proteus mirabilis and Escherichia coli.
The parallel relation between the invasion and cytotoxicity in this study was not demonstrated in other microorganisms. Fleiszig et al. (1995) reported that $P$. aeruginosa isolates recovered from human infections showed a significant inverse correlation between the ability to induce cytotoxicity and epithelial cell invasion. Although, Gupta et al. (1994) demonstrated that disabled cytotoxicity by mutation of a transcriptional activator called ExsA, encoded by exsA, showing ability to detect invasion at later time points. This is because cytotoxic bacteria would enter the epithelial cells causing death of these cells consequently, allowing penetration of gentamycin antibiotic into the cells, rendering gentamycin survival assays incapable of detecting the presence of intracellular bacteria accurately. This would also explain why there was an inverse correlation among clinical isolates between their ability to invade cells as measured by gentamicin assays and their cytotoxic capacity (Fleiszig et al., 1998). On the other hand, Fleiszig et al. (1996) and (1997) suggested that $P$. aeruginosa cytotoxicity may be invasion dependent. Moreover, Evans et al. (1998) and Fleiszig et al. (1998) showed that cytotoxic strains of $P$. aeruginosa are inherently capable of invasion. Evans et al. (1998) reported that invasion and cytotoxicity are independent events, therefore, the therapeutic approaches aimed at preventing invasion were not able to block cytotoxicity. The significance of these results indicated that there is more than one pathway for disease caused by pathogenic isolates, consequently, different therapeutic strategies might be necessary to manage Proteus infection.

Adhesion capability of all Proteus isolates was demonstrated 
with different extents in this study. Adherence to mammalian cells required in the early stage of colonization and biofilm formation and may be mediated by a specific protein, toxin and unique appendage (O'Toole and Roberto, 1998). However, the difference in adhesion capabilities for isolates may be due to strain dependent (Raivio, 2005). Gram-negative uropathogens produce an assortment of adhesins including those attached to the tip of hair-like projections, known as fimbriae or pili, as well as adhesins anchored directly within bacterial cell membranes, known as nonfimbrial adhesins (Jacobsen et al., 2008). There was tight relation between invasion and adherence, once initial attachment and permanent adherence commenced on the surface of uroepithelial cells, the establishment uropathogenic E. coli infection occurs through the colonization of the bladder by the invasion of host cells and the subsequent formation of biofilms (Mulvey, 2002).

Concerning the production of urease enzymes, all Proteus spp. showed high production of urease enzymes. This was similar to previous reports by Gendlina et al. (2002) who demonstrated that Proteus spp. produced high amount of urease compared with other bacteria. Urease enzyme was known to hydrolyzes urea into ammonia and ultimately carbon dioxide. As a result of ammonia production, an increase in local $\mathrm{pH}$ causes precipitation of normally soluble calcium and magnesium ions. These salt crystals can grow to remarkable size to produce bladder and kidney stones (Li et al., 2002) which are a hallmark of infections with Proteus spp. Proteus spp. collected in this study did not show any protease or lipase activities. This was contradictory to the work done by Stankowska et al. (2008) who demonstrated the proteolytic activities of 12 Proteus mirabilis, however they proved that the virulence factors in P. mirabilis, were strain-specific. This was also demonstrated in this study that only $42 \%$ of the collected samples were able to produce elastase activities. Swarming migration was known to be an important virulence factor, the present work showed that all Proteus isolates exhibited swarming migration.

In general, many of infections caused by the pathogenic strains were due to the acquisition of large blocks of virulence genes from a common microbial ancestor, which can be disseminated to other bacteria via horizontal gene transfer (Hentzer and Givskov, 2003). The widespread use of antibiotic since the middle of the last century has created a powerful selection force driving the evolution of drug resistant bacterial pathogens (Levy, 1992 and Virve et al., 2004). This was clearly demonstrated in this study. The antibiotic susceptibility pattern of the 5 clinical isolates showed a slight susceptibility to Ciprofor, Garamycin, Augmentin and Tazocin which are members of $\beta$ lactams antibiotics. The resistance could be explained on the basis of observation by Bush et al. (1995) who showed that members of the family enterobacteriaceae commonly express plasmid encoded $\beta$ lactamases (e.g., TEM-1, TEM-2, and SHV-1). which confer resistance to penicillins (Knothe et al., 1983). Resistance generally arises due to mutations in penicillin binding proteins, production of metallo- $\beta$ lactamases, or resistance to diffusion across the bacterial outer membrane (Piddock et al., 1997 and George et al., 2005). The most common 
mechanism of resistance in Gram negative bacteria causing clinically significant infection remains the production of $\beta$-lactamases, including chromosome and plasmid encoded enzymes (Bush et al., 1995).

Plasmids isolated from the selected 5 clinical isolates (exhibited high virulence factors) showed the same pattern in 3 isolates which was different from the other 2 isolates. However a diverse pattern was detected in Proteus mirabilis (Pr2, Pr12 and Pr24) as well as Proteus penneri (Pr6 and Pr20) isolates. This explains the difference in sensitivity of the isolated towards the different antibiotics. According to previous studies, it is well known that most Gram negative bacteria are harbouring plasmids (Helling, et al., 1981, Parkhill, et al., 2001 and Virve, et al., 2004) that are responsible for antibiotic resistance and some virulence factors.

As a result of plasmid curing for the 5 clinical isolates, bacteria lost their resistance towards different antibiotics and became sensitive to different previously exhibited resistance towards them. This demonstrated that the antibiotic resistant genes are plasmid encoded rather than chromosomal. This was confirmed previously the relation between plasmids and antibiotic resistance (Laraki et al., 1999 and Lauretti et al., 1999).

In addition, only two virulence factors were lost upon plasmid curing (invasion and adherence capabilities), however no effect was detected with the other virulence factors tested. This assessed the relation between plasmids and virulence factors. Moreover, it demonstrated that the tested virulence factors were chromosomal coded rather than plasmid coded
(Stankowska et al., 2008) except for invasion and adherence capabilities.

Previous reports correlated plasmids with virulence and curing plasmids resulted in loss of virulence. Rotger and Casadesus (1999) reported that virulence factors responsible for pathogenicity in enteric bacteria are often encoded by plasmids, as in E. coli, Yersinia spp. and Shigella spp. Sekizaki et al. (1989) found that a reduction in virulence of $E$. coli against chickens was correlated with loss of a large plasmid with molecular size of 95 kilobases (kb). Jackson et al. 1999 reported that cured strains of phytopathogen Pseudomonas syringae pv. phaseolicola (Pph) form the 154-kb plasmid lost virulence toward bean. Paetzold et al. (2007) reported that invasion of Shigella flexneri was due to the Shigella entry region (SER), carried in a large virulence plasmid.

\section{REFERENCES}

Allison, C., Lai, H.C. and Hughes, C. (1992). Co-ordinate expression of virulence genes during swarm-cell differentiation and population migration of Proteus mirabilis. Mol. Microbiol. 6: 1583-1591.

Ayora, S., Lindgren, P. and Götz, F. (1994). Biochemical properties of a novel metalloprotease from Staphylococcus hyicus subsp. hyicus involved in extracellular lipase processing. J. Bacteriol. 176:32183223.

Burall, L.S., Harro, J.M., Li, X., Lockatell, C.V., Himpsl, S.D., Hebel, J.R., Johnson, D.E. and Mobley, H.L. (2004). Proteus mirabilis genes that contribute to pathogenesis of urinary tract infection: identification of 25 signature-tagged mutants attenuated at least 100-fold. Infect. Immun. 72:2922-2938.

Bush, K., G. A. Jacoby, and A. A. Medeiros. (1995). A functional classification scheme for beta-lactamases and its correlation with molecular structure. Antimicrob. Agents Chemother. 39:1211-1233. 
Canton, R. and Coque, T.M. (2006). The CTX-M beta-lactamase pandemic. Curr. Opin. Microbiol. 9: 466-475.

Cheesbrough, M. (2000). District Laboratory Practice in Tropical Countries, Part 2. Cambridge University Press, Cambridge, UK; PP 434.

Coker, C., Poore, C.A., Li, X. and Mobley, H.L. (2000). Pathogenesis of Proteus mirabilis urinary tract infection. Microbes Infect. 2:14971505.

Coque, T.M., Novais, A., Carattoli, A., Poirel, L., Pitout, J., Peixe, L., Baquero, F., Canton, R. and Nordmann, P. (2008). Dissemination of clonally related Escherichia coli strains expressing extendedspectrum beta-lactamase CTX M-15. Emerg. Infect. Dis. 14:195-200.

Evans, D.J., Frank, D.W., Finck-Barbancon, V., Wu, C., Fleiszig, S.M.J. (1998). Pseudomonas aeruginosa invasion and cytotoxicity are independent events, both of which involve protein tyrosine kinase activity. Infect. Immun. 66:1453-1459

Finlay, B.B. and Falkow, S. (1997). Common themes in microbial pathogenicity revisited. Microb. Mol. Biol. Rev. 16:136-169.

Fleiszig, S.M.J., Zaidi, T.S. and Pier, G.B. (1995). Pseudomonas aeruginosa survival and multiplication within corneal epithelial cells in vitro. Infect. Immun. 63:4072-4077.

Fleiszig, S.M.J., Zaidi, T.S., Preston, M.J., Grout, M. Evans, D.J. and Pier, G.B. (1996). The relationship between cytotoxicity and epithelial cell invasion by corneal isolates of Pseudomonas aeruginosa. Infect. Immun. 64:2288-2294.

Fleiszig, S.M.J., Wiener-Kronish, J.P., Miyazaki, H., Vallas, V., Mostov, K.E., Kanda, D., Sawa, T., Yen, T.S.B. and Frank, D.W. (1997). Pseudomonas aeruginosa mediated cytotoxicity and invasion correlate to distinct genotypes at the loci encoding exoenzyme $\mathrm{S}$. Infect. Immun. 65:579-586.

Fleiszig, S.M.J., Lee, E.J. and Wu, C. (1998). Cytotoxic strains of Pseudomonas aeruginosa can damage the intact corneal surface in vitro. Clao $J$. 24:41-47.

Fraser, G. M., Claret, L., Furness, R., Gupta, S. and Hughes, C. (2002). Swarming coupled expression of the

$\begin{aligned} & \text { Proteus mirabilis } \\ & \text { haemolysin operon. }\end{aligned}$
148:2191-2201

Furuya, N., Hirakata, Y., Tomono, K., Matsumoto, T., Tateda, K. and Kaku, M. (1993). Mortality rates amongst mice with endogenous septicaemia caused by Pseudomonas aeruginosa isolates from various clinical sources. J. Med. Microbiol. 39:141-146.

Gendlina I., Gutman, D.M., Thomas, V., Collins, C.M. (2002). Ureadependent signal transduction by the virulence regulator UreR. $J \mathrm{Biol}$ Chem. 277:37349-37358.

George, A., Jacoby, M.D., Silvia, L. and Munoz-Price, M.D. (2005). Mechanisms of disease: The New beta-Lactamases. N. Engl. J. Med. 352:380-91.

Gupta, S.K., Berk, R.S., Masinick, S. and Hazlett, L.D. (1994). Pili and lipopolysaccharide of Pseudomonas aeruginosa bind to the glycolipid asialo GM1. Infect. Immun. 62:4572-4579.

Gygi, D., Bailey, M.J., Allison, C. and Hughes, C. (1995). Requirement for FlhA in flagella assembly and swarm-cell differentiation by Proteus mirabilis. Mol Microbiol 15:761-769

Hacker, J. and Kaper, J.B. (2000). Pathogenicity islands and the evolution of microbes. Annu. Rev. Microbiol. 54:641-79

Helling, R. B., Kinney, T. and Adams, J. (1981). The maintenance of plasmid-containing organisms in populations of Escherichia coli. J. Gen. Microbiol. 12: 129-41.

Hentzer, M. and Givskov, M. (2003). Pharmacological inhibition of quorum sensing for the treatment of chronic bacterial infections. J. Clin. Investig. 112:1300-1307.

Holt, J.G. and Williams, S.T. (1989). In Bergey's Manual of Systematic Bacteriology. Vol. 3 Williams and Wilkins Co., Baltimore USA, PP 443-457.

Jackson, R.W., Athanassopoulos, E., Tsiamis, G., Mansfield, J.W., Sesma, A., Arnold, D.L., Gibbon, M.J., Murillo, J., Taylori, J.D. and Vivian, A. (1999). Identification of a pathogenicity island, which contains genes for virulence and avirulence, on a large native 
plasmid in the bean pathogen Pseudomonas syringae pathovar phaseolicola. Proc. Natl. Acad. Sci. USA. 96:10875-10880.

Jacobsen, S.M., Stickler, D.J. Mobley, H.L.T. and Shirtliff, M.E. (2008). Complicated Catheter-Associated Urinary Tract Infections Due to Escherichia coli and Proteus mirabilis Clin. Microbiol. Reviews 21: 26-59.

James, A.M. and John, D. (1998). Basic cell culture technique and the maintenance of cell lines. Basic cell culture 99-138.

Johnson, D.E., Russell, R.G., Lockatell, C.V., Zulty, J.C., Warren, J.W. and Mobley, H.L. (1993). Contribution of Proteus mirabilis urease to persistence, urolithiasis, and acute pyelonephritis in a mouse model of ascending urinary tract infection. Infect.Immun.61:2748-2754.

Johnson, J.R., Kuskowski, M.A., Owens, K., Gajewski, A. and Winokur, P.L. (2003). Phylogenetic origin and virulence genotype in relation to resistance to fluoroquinolones and / or extended - spectrum cephalosporins and cephamycins among Escherichia coli isolates from animals and humans. J. Infect. Dis. 188:759-768.

Jones, B.D., Lockatell, C.V., Johnson, D.E., Warren, J.W. and Mobley, H.L. (1990). Construction of a ureasenegative mutant of Proteus mirabilis: analysis of virulence in a mouse model of ascending urinary tract infection. Infect. Immun. 58:1120-1123.

Knothe, H., Shah, P., Krcmery, V., Antal, M. and Mitsuhashi S. (1983). Transferable resistance to cefotaxime, cefoxitin, cefamandole and cefuroxime in clinical isolates of Klebsiella pneumoniae and Serratia marcescens. Infec. 11:315-317.

Korn, A., Rajabi, Z., Wassum, B., Ruiner, W. and Nixdorff, K. (1995). Enhancement of uptake of lipopolysaccharide in macrophages by the major outer membrane protein OmpA of Gram-negative bacteria. Infect. Immun. 63:26972705.

Krajden, S., Fuksa, M., Lizewski, W., Barton, L. and Lee, A. (1984). Proteus penneri and urinary calculi formation. J. Clin. Microbiol. 19:541-542.
Kueng, W., Silber, E. and Eppenberger, U. (1986). Quantification of cells cultured on 96-well plates. Anal. Biochem. 159:109-113.

Kwon, D.Y. and Rhee, J.S. (1986). Asimple and rapid colometric method for determination of free fatty acid for lipase assay. JAOCS 63:69-92.

Laraki, N., Franceschini, N., Rossolini, G.M., Santucci, P., Meunier, C., De Pauw, E., Amicosante, G., Frere, J.M. and Galleni, M. (1999). Biochemical characterization of the Pseudomonas aeruginosa 101 / 1477 metallo- $\beta$-lactamase IMP-1 produced by Escherichia coli. Antimicrob. Agen. Chemother. 43:902-906.

Lauretti, L., Riccio, M.L., Mazzariol, A., Cornaglia, G., Amicosante, G., Fontana, R. and Rossolini, G.M. (1999). Cloning and characterization of blaVIM, a new integron-borne metallo- $\beta$ lactamase gene from a Pseudomonas aeruginosa clinical isolate. Antimicrob. Agent. Chemother. 43:1584-1590.

Levy, S.B. (1992). The Antibiotic Paradox: How Miracle Drugs are Destroying the Miracle, 1st edn. Plenum Press, New York, NY, USA. PP 114-123.

Li, X., Zhao, H., Lockatell, C.V., Drachenberg, C.B., Johnson, D. E. and Mobley, H.L. (2002). Visualization of Proteus mirabilis within the matrix of urease-induced bladder stones during experimental urinary tract infection. Infect. Immun. 70:389-394.

Liaw, S.J., Lai, H.C., Ho, S.W., Luh, K. T. and Wang, W.B. (2000). Inhibition of virulence factor expression and swarming differentiation in Proteus mirabilis by $p$-nitrophenylglycerol. J. Med. Microbiol. 49:725-731.

Liaw, S.J., Lai, H.C., Ho, S.W., Luh, K. T. and Wang, W. B. (2001). Characterisation of p-nitrophenylglycerol -resistant Proteus mirabilis superswarming mutants. J. Med. Microbiol. 50:1039-1048.

Liaw, S.J., Lai, H.C. and Wang, W.B. (2004). Modulation of swarming and virulence by fatty acids through the RsbA protein in Proteus mirabilis. Infect. Immun. 72:6836-6845.

Maltezou, H.C. (2009). Metallo- $\beta$-lactamases in Gram negative bacteria: introducing the era of pan-resistance. Int. J. Antimicrob. Agen. 33:405407. 
Mobley, H.L. and Warren, J.W. (1987). Urease-positive bacteriuria and obstruction of long term urinary catheters. J. Clin. Microbiol. 25:2216-2217.

Mobley, H.L.T., Chippendale, G.R., Swihart, K.G., and Welch, R.A. (1991). Cytotoxicity of the HpmA hemolysin and urease of Proteus mirabilis and Proteus vulgaris against cultured human renal proximal tubular epithelial cells. Infect. Immun. 59:2036-2042.

Mulvey, M. A. (2002). Adhesion and entry of uropathogenic Escherichia coli. Cell. Microbiol. 4:257-271.

O'Toole, G.A. and Roberto, K. (1998). Flagellar and twitching motility are necessary for Pseudomonas aeruginosa biofilm development. Mol. Microbiol. 30:295-304.

Ofek, I. and Doyle, R.J. (1994). Bacterial adhesion to cells and tissues. Chapman and Hall, Ltd., London, United Kingdom, PP 164.

Parkhill, J., Dougan, G., and James, K. D. (2001). Complete genome sequence of a multiple drug resistant Salmonella enterica serovar Typhi CT18. Nature 413:848-52.

Peerbooms, P.G., Verweij, A.M. and MacLaren, D. M. (1984). Vero cell invasiveness of Proteus mirabilis. Infect. Immun. 43:1068-107.

Penner, J.L. (1984). Genus XI Proteus, p. 491-494. In N. R. Krieg and J. G. Holt (ed.), Bergey's manual of systemic bacteriology, vol. 1 . Williams and Wilkins Co., Baltimore, MD.

Perna, N.T., Plunkett, G.III, Burland, V., Mau, B., Glasner, J.D., Rose, D.J., Mayhew, G.F., Evans, P.S., Gregor, J., Kirkpatrick, H.A., Pósfai, G., Hackett, J., Klink, S., Boutin, A., Shao, Y., Miller, L., Grotbeck, E.J., Davis, N.W., Lim, A., Dimalanta, E.T., Potamousis, K.D., Apodaca, J., Anantharaman, T.S., Lin, J., Yen, G., Schwartz, D.C., Welch, R.A. and Blattner, F.R. (2001). Genome sequence of enterohaemorrhagic Escherichia coli O157:H7. Nature 409:463-466.

Piddock, L.J, Walters, R. N., Jin, Y. F., Turner, H. L., Gascoyne-Binzi, D. M. and Hawkey, P. M.
(1997).Prevalence and mechanism of resistance to 'third-generation' cephalosporins in clinically relevant isolates of Enterobacteriaceae from 43 hospitals in the UK, 1990-1991. J. Antimicrob. Chemother. 39:177-187.

Plotkowaski, M., Saliba, A.M. Pereira, S.H. Cervante, M.P. and Bajolet-laudiant, O. (1994). Pseudomonas aeruginosa selective adherence to and entry into human endothelial cells. Infec. Imm. 62:5456-5463.

Raivio, T.L. (2005). Envelope stress responses and Gram-negative bacterial pathogenesis. Mol. Microbiol. 56:1119-1128.

Rotger, R. and Casadesus, J. (1999). The virulence plasmids of Salmonella. Internatl. Microbiol. 2:177-184.

Sekizaki, T., Nonomura, I., and Imada, Y. (1989). Loss of virulence associated with plasmid curing of chicken pathogenic Escherichia coli. Jap. J. Vet. Sci. 51:659-661.

Stankowska, D., Kwinkowski, M., and Kaca, W. (2008). Quantification of Proteus mirabilis virulence factors and modulation by acylated homoserine lactones. J. Microbiol. Immunol. Infect. 41:243-253.

Tang, H., Kays M. and Prince, A. (1995). Role of Pseudomonas aeruginosa pili in acute pulmonary infection. Infect. Immun. 63:1278-1285.

Tolmasky, M.E., Actic, L.A. and Crosa, J.H. (1993). Virulence plasmid. In, Plasmid, A practical approach. Edited by Hardy KG. Oirl press at oxford university press, Tokyo Oxford, New York, PP. 387389.

Virve I.E., Bennett, P.M., Livermore, D.M. and Hall, L.M.C. (2004). Enhancement of host fitness by the sul2-coding plasmid p9123 in the absence of selective pressure. $J$. Antimicrob. Chem. 53:958-963.

Warren, J.W., Tenney, J.H., Hoopes, J.M., Muncie, H.L. and Anthony, W.C. (1982). A prospective microbiologic study of bacteriuria in patients with chronic indwelling urethral catheters. J. Infect. Dis.146:719-723.

Weatherburn, M.W. (1967). Phenolhypochlorite reaction for determination of ammonia. Anal. Chem. 39:971-974. 


\section{ARABIC SUMMARY}

\section{وساطة البلازميد فى عوامل الضراوة لعزلات بروتيس}

خالد زكريا البغدادى' ـ محمد مبروك محمد ابو الوفا' ـ مديحة عثمان إبراهيم غباثى'

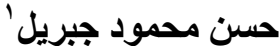

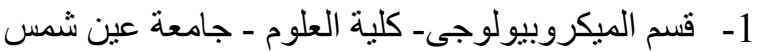

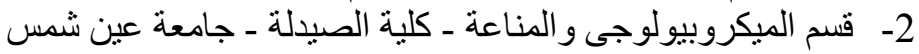

تم تعيين بعض عوامل الضراوة وهى الإختراقية ،الالتصاق ،السمية لخلايا العائل ،انتاج بعض الإنس الإنزيمات

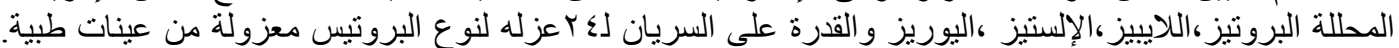

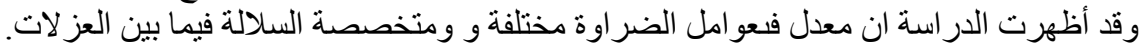

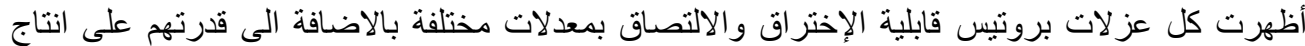

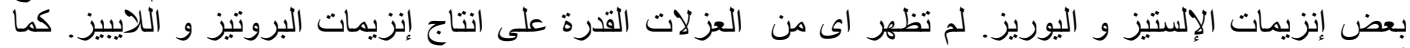

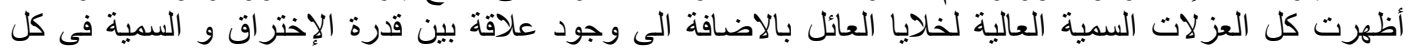

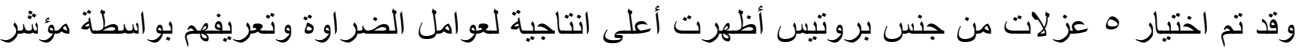
العزلات

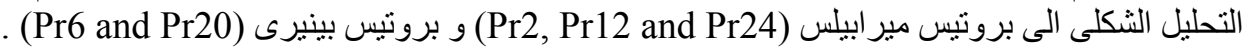

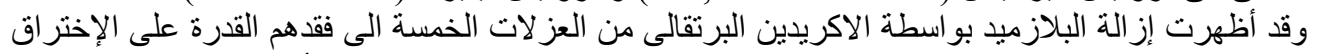

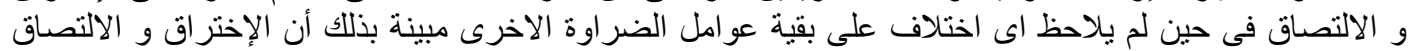

